\title{
Human bocavirus 1 and 3 infection in children with acute gastroenteritis in Brazil
}

\author{
Teresinha Teixeira de Sousa', Menira Souza', Fabíola Souza Fiaccadori', Ana Maria Tavares Borges', \\ Paulo Sucasas da Costa ${ }^{2}$, Divina das Dôres de Paula Cardoso ${ }^{1 /+}$ \\ ${ }^{1}$ Laboratório de Virologia Humana, Instituto de Patologia Tropical e Saúde Pública \\ ${ }^{2}$ Faculdade de Medicina, Universidade Federal de Goiás, Goiânia, GO, Brasil
}

To determine the positivity rate of human bocavirus (HBoV) 1 and 3 among children who presented with acute gastroenteritis symptoms during the period of 1994-2004 in the Central-West Region of Brazil, 762 faecal samples were tested using polymerase chain reaction (PCR) for the detection of HBoV DNA. Primers for a segment of the non-structural viral protein 1 (NS1) gene of $H B o V-1$ and $H B o V-3$ were used. Twelve HBoV-positive samples were further characterised via genomic sequencing and phylogenetic analysis. Of the samples tested, $5.8 \%(n=44)$ were positive for HBoV-1 or HBoV-3 and co-infection was observed in 14 (31.8\%) of the $44 \mathrm{HBoV}$-positive samples. Nine of the 14 samples were also positive for Rotavirus A and five were positive for Aichi virus. The genomic sequencing of the NS1 partial sequence of $12 \mathrm{HBoV}$-samples showed that 11 samples were characterised as HBoV-1 and that one was characterised as HBoV-3. The phylogenetic analysis showed that the HBoV-1 samples had a high sequence homology to others previously identified in China, Sweden and Brazil. This is the first study conducted in the Central-West Region of Brazil to detect $\mathrm{HBoV}-1$ and $\mathrm{HBoV}-3$ in faecal samples from children with acute gastroenteritis. Further studies are required to define the role of HBoVs as aetiological agents of gastroenteritis.

Key words: human bocavirus - acute gastroenteritis - molecular characterisation - Brazil

Human bocaviruses (HBoVs) were first detected in a pool of respiratory aspirates obtained from children presenting with respiratory illness (Allander et al. 2005) and, more recently, in faecal samples from children presenting with fever and diarrhoea with or without associated respiratory symptoms (Albuquerque et al. 2007).

The HBoVs belong to the Parvoviridae family, subfamily Parvovirinae, genus Bocavirus (ICTV 2008). These agents are non-enveloped and have a diameter of approximately $18-26 \mathrm{~nm}$ and their genomes consist of single-stranded DNA of positive or negative polarity. The genome has three open reading frames (ORFs). The first ORF encodes for a non-structural viral protein (NS1) of unknown function for HBoVs. The second ORF encodes for two major structural proteins (VP1 and VP2) that comprise the viral capsid. The third ORF encodes for a non-structural nuclear phosphoprotein (NP1) (Allander et al. 2005, Schildgen et al. 2008, Jartti et al. 2012).

Genomic analysis of the structural (VP1/VP2) and non-structural regions (NS1 and NP1) of the HBoV have permitted the identification of four viral species: $\mathrm{HBoV}-1$, HBoV-2, HBoV-3 and HBoV-4 (Kapoor et al. 2010).

Since its discovery, the $\mathrm{HBoV}-1$ detection rate has varied from $2-19 \%$ in patients with upper or lower respiratory disease (Allander et al. 2005, Lau et al. 2007, Monteny et al. 2007, Tozer et al. 2009). HBoV-2, HBoV-3

Financial support: CNPq, CAPES, UFG

+Corresponding author:divina@prppg.ufg.br

Received 7 December 2011

Accepted 10 May 2012 and $\mathrm{HBoV}-4$ have mainly been detected in stool samples, with $\mathrm{HBoV}-2$ and possibly $\mathrm{HBoV}-3$ being associated with gastroenteritis (Lee et al. 2007, Jartti et al. 2012). However, several studies (Campe et al. 2008, Arthur et al. 2009, Han et al. 2009), including those conducted in Brazil (Albuquerque et al. 2007, Santos et al. 2010), have attempted to detect HBoVs in faecal samples obtained from individuals presenting with acute gastroenteritis.

In addition, in the Central-West Region of Brazil, many studies have focused on the investigation of other gastroenteric agents in this population (Cardoso et al. 1989, 2003, Camarota et al. 1992, Borges et al. 2006, Oh et al. 2006, Andreasi et al. 2008, Silva et al. 2009). Therefore, the objective of this study, the first conducted in this region, was the detection of $\mathrm{HBoV}-1$ and $\mathrm{HBoV}-3$ in faecal samples obtained from children under five years of age presenting with acute gastroenteritis.

\section{SUBJECTS, MATERIALS AND METHODS}

Material of study - Seven hundred sixty-two faecal samples were obtained from an equal number of children under five years of age presenting with acute gastroenteritis. The children underwent care in three Health Care units located in the cities of Goiânia, state of Goiás, Brasília, Federal District, and Campo Grande, state of Mato Grosso do Sul, Central-West Region of Brazil. Of the total of samples, 401 were obtained from children from Goiânia during 1998-2002, 130 were collected from Brasília during the periods of 1994-1996 and 1998-2002 and 231 samples originated from Campo Grande during 2000-2004.

All faecal samples were previously tested for group A rotavirus (RVA), adenovirus, calicivirus and astrovirus and the samples obtained in Campo Grande were screened for Aichi virus. 
No bacteriological analysis was conducted in the present study.

The samples were collected after a written informed consent was provided by parents or legal guardians. The study was approved by the Committee of Ethical in Research of the Federal University of Goiás (protocol 004/2000).

HBoV-1 and HBoV-3 detection - The HBoVs were detected using polymerase chain reaction (PCR) assays according to the protocol described by Albuquerque et al. (2007) with certain modifications. The viral DNA was extracted using a commercial kit (Wizard Genomic DNA Purification Kit, Promega) according to the manufacturer's instructions. The extracted material was amplified using the primer pairs $\mathrm{HBoV} 01.2$ and $\mathrm{HBoV} 02.2$ (Sloots et al. 2006) to specifically target a segment of the NS1 gene of HBoV-1 and HBoV-3. The reaction mixture was prepared for a final volume of $25 \mu \mathrm{L}$ using $5 \mathrm{x}$ reaction buffer (PCR buffer - $20 \mathrm{mM}$ TRIS-HCL pH 8, 4/20 $\mathrm{mM} \mathrm{KCL} 500 \mathrm{~m} \mathrm{mM}), 10 \mathrm{mM}$ of each deoxynucleotide triphosphate, $25 \mathrm{mM} \mathrm{MgCl}, 0.2 \mu \mathrm{M}$ of each specific primer and $2 \mathrm{U} / \mu \mathrm{L}$ of Taq DNA polymerase (Invitrogen/ Life Technologies). The amplification was performed using the following conditions: $95^{\circ} \mathrm{C}$ for $15 \mathrm{~min}, 45$ cycles of $94^{\circ} \mathrm{C}$ for $20 \mathrm{sec}, 56^{\circ} \mathrm{C}$ for $20 \mathrm{sec}$ and $72^{\circ} \mathrm{C}$ for $30 \mathrm{sec}$ and a final extension at $72^{\circ} \mathrm{C}$ for $5 \mathrm{~min}$. Positive controls (samples that were previously tested for $\mathrm{HBoV}-1 / \mathrm{HBoV}-3$ using PCR and sequencing) and negative controls (Milli-Q water) were used in all reactions. The amplicons were resolved by electrophoresis on a $1.5 \%$ agarose gel and visualised using a UV light transilluminator (Macro Vue UV-20-Hoefer Scientific Instruments) for the observation of the expected size fragments (291 bp).

Determination of the HBoV species - Genomic sequencing - For the determination of viral species, genomic sequencing was performed using PCR products purified with the QIAquik ${ }^{\circledR}$ system (Qiagen, São Paulo, Brazil) and the primer pair described above. The sequencing reaction was conducted following the methodology described by Sanger et al. (1977) using a ABI Prism 3130 Genetic Analyser (Applied Biosystems, Foster City, CA) and the BigDye Terminator Cycle Sequencing ABI 3130 kit (Applied Biosystems, Foster City, CA).

Phylogenetic analysis - The quality of the obtained nucleotide sequences was analysed using the program Phred and the program CLUSTALX (Tompson et al. 1997) was then used to compare to other sequences deposited in GenBank. The phylogenetic analyses and tree generation were performed using CLUSTALX with the neighbour-joining algorithm (Saitou \& Nei 1987). The following reference sequences were used for the comparative analysis: $\mathrm{HBoV}-1$ (DQ000495, DQ000496, EF450739, EF560207, EF560209 and EF560207), HBoV-2 (EU062213 and FJ170280) and HBoV-3 (EU918738, GQ887666 and GQ887667).

Statistical analysis - The statistical analysis of the data was performed with the software Epi Info version 6.0 using the chi-squared $\left(X^{2}\right)$ test and the exact Fisher test, when appropriate. Statistical significance was assessed at a $p$ value of $<0.05$.

\section{RESULTS}

HBoV 1 and 3 detection - An overall positivity rate of 5.8\% (44/762) was observed for HBoV-land HBoV-3. When the city of the sample collection was considered, similar detection rates were observed: $5 \%, 6.5 \%$ and $6.9 \%$ for Goiânia, Campo Grande and Brasília, respectively $(\mathrm{p}>0.05)$. Regarding the children's gender, similar rates were also detected for all three cities with global detection rates of $5.7 \%$ and $5.8 \%$ for males and females, respectively $(p>0.05)$. No significant differences in the $\mathrm{HBoV}-1$ and $\mathrm{HBoV}-3$ positivity rates were observed for any particular age group $(p>0.05)$.

The data were also analysed to assess the possibility of a seasonal circulation pattern for HBoV-1 and HBoV-3. Positivity rates of $5.4 \%$ and $6.3 \%$ were observed for the rainy and dry seasons, respectively $(\mathrm{p}>0.05)$.

The data were also analysed for the occurrence of coinfection with other previously identified gastroenteric viruses and a global co-infection rate of $31.8 \%$ was observed. Of the total samples that presented with a co-infection, nine were also positive for RVA and five were positive for Aichi virus. However, Aichi virus detection was only performed on the samples obtained in Campo Grande.

Identification of $\mathrm{HBOV}$ species - Twelve of the 44 HBoV-positive samples identified via PCR were sequenced and a phylogenetic analysis was performed using a partial sequence of the NS1 gene. Of the total samples, 11 were characterised as $\mathrm{HBoV}-1$ and one was characterised as $\mathrm{HBoV}-3$ (Figure). The samples identified as HBoV-1 were obtained from children in the three cities of the study and three samples, two from Brasília and one from Campo Grande, showed $100 \%$ nucleotide identity. Additionally, four isolates from Campo Grande showed 97\% identity and formed an isolated group. The sample characterised as $\mathrm{HBoV}-3$ was obtained from a child in Brasília.

\section{DISCUSSION}

$\mathrm{HBoV}$ detection in faecal samples from individuals with acute gastroenteritis has gained importance following the positive identification of bocavirus in faecal samples from individuals throughout the world (Albuquerque et al. 2007, Lau et al. 2007, Lee et al. 2007, Monteny et al. 2007, Vicente et al. 2007, Han et al. 2009, Chow et al. 2010, Kantola et al. 2010, Jin et al. 2011, Xu et al. 2011). In Brazil, only three studies have been published regarding $\mathrm{HBoV}$ detection in children with acute gastroenteritis (Albuquerque et al. 2007, Santos et al. 2010, Proença-Modena et al. 2011) and this is the first study conducted in the Central-West Region of Brazil. In addition, our study is unique because the study period of 1994-2004 allows us to assess HBoV-1 and HBoV-3 circulation prior to the discovery of this virus.

In this study, a detection rate of $5.8 \%$ was observed for $\mathrm{HBoV}-1$ or $\mathrm{HBoV}-3$, which was similar to that reported by other studies conducted in different parts of the world (Lee et al. 2007, Vicente et al. 2007, Cheng et al. 2008, Yu et al. 2008), including Brazil (Albuquerque et al. 2007). Based on the mean occurrence of other gastroenteric viruses in the region, HBoV-1 could be considered the third most common after RVAs and human cali- 


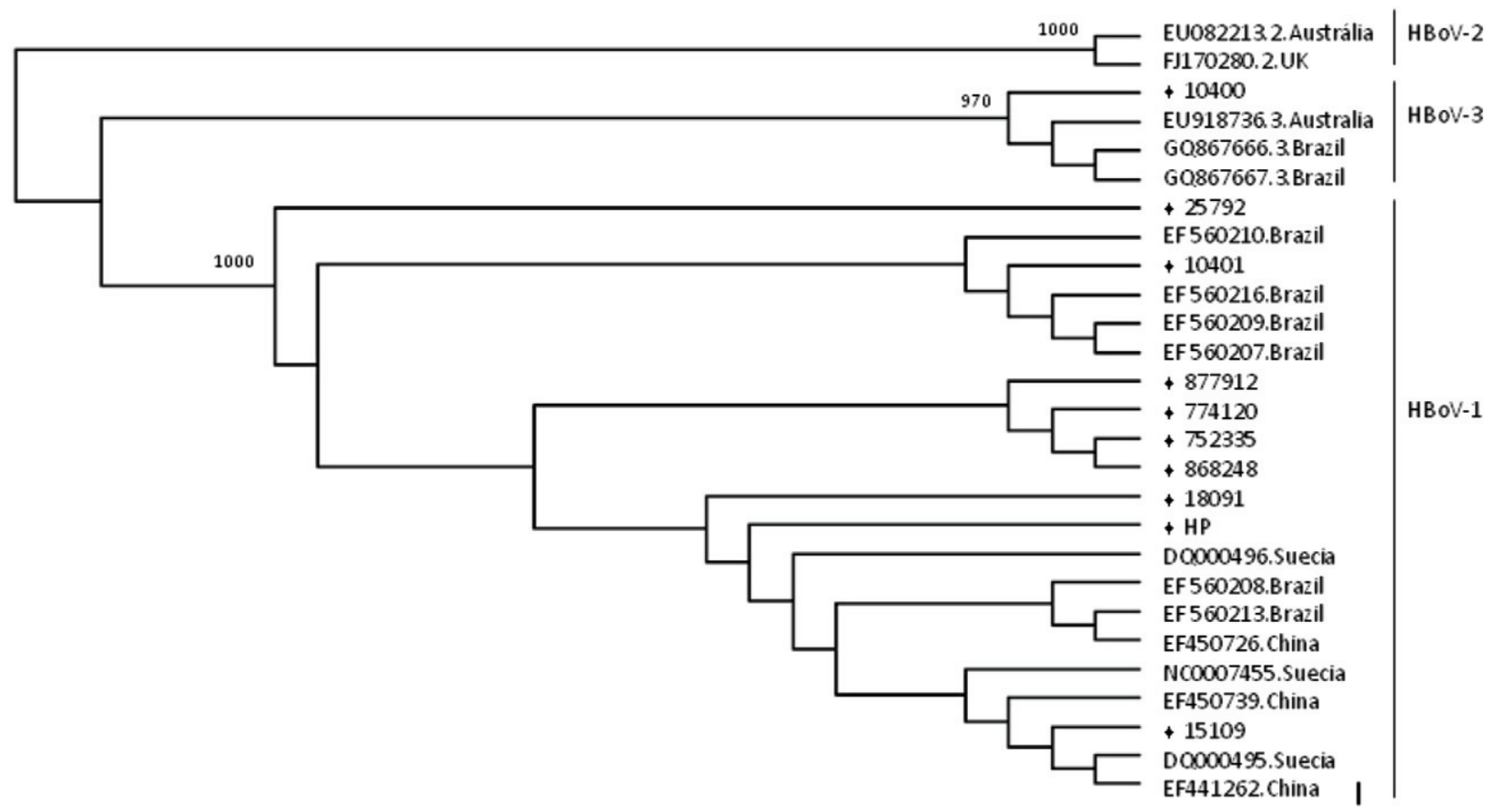

Phylogenetic analysis of the nucleotide sequences from a region of the human bocaviruses (HBoVs) gene. The diamonds represent the samples obtained in this study (Goiânia, state of Goíás, Brasília, Federal District, and Campo Grande, state of Mato Grosso do Sul). Samples with 100\% nucleotide identity were designated haplotypes, which represents the following samples: 916014, 10352 and 15097.

civiruses (Cardoso et al. 2003, Costa et al. 2004, Borges et al. 2006, Santos et al. 2007, Andreasi et al. 2008,). Additionally, it must be noted that primer pairs that detect only $\mathrm{HBoV}$ species 1 and 3 were used in this study and if one considers that species 2 appears to be predominant in individuals with gastroenteritis (Arthur et al. 2009, Chow et al. 2010), the observed positivity rate for HBoVs may be underestimated. Therefore, future studies should be conducted to confirm this assumption.

In this study, a similar detection rate for $\mathrm{HBoV}-1$ was observed in both male and female children, which is in agreement with other studies conducted in other parts of the world (Yu et al. 2008, Han et al. 2009). This finding reinforces data from previous investigations conducted in the region that show no difference in gastroenteric virus detection rates regardless of the children's gender (Camarota et al. 1992, Borges et al. 2006, Santos et al. 2007).

A significant correlation between the occurrence of gastroenteric viruses and the age of the children has been observed in the Central-West Region of Brazil. For example, RVAs have been predominantly detected among children up to 24 months of age (Camarota et al. 1992, Cardoso et al. 2003, Costa et al. 2004), with a similar age range observed for astroviruses (Silva et al. 2009) and adenoviruses (Cardoso et al. 1989). The caliciviruses were detected in children up to 36 months of age (or 36 months-old) (Borges et al. 2006).

A study conducted in South Korea reported a higher detection rate for $\mathrm{HBoVs}$ among children in the 25-30month-old group (Yu et al. 2008). In the present study, HBoV-1 and HBoV-3 were detected in children less than five years of age, which is in agreement with other stud- ies conducted in different parts of the world (Campe et al. 2008, Huang et al. 2009, Karalar et al. 2009, Tozer et al. 2009), including Brazil (Albuquerque et al. 2007).

A seasonal pattern of gastroenteric virus circulation was observed in previous studies conducted in Brazil. In the Central-West Region of the country, the four seasons of the year are not well defined and only a dry and a rainy period are observed, corresponding to the months of April-August and September-March, respectively. Notably, RVAs are mainly detected during the dry season (Cardoso et al. 2003, Costa et al. 2004), whereas astroviruses and caliciviruses are more prevalent in the rainy period (Borges et al. 2006, Santos et al. 2007). However, in the present investigation, a seasonal pattern of circulation was not observed for HBoV-1, which was detected throughout the year during the study period. For comparative purposes, data regarding viral seasonality are scarce and, to our knowledge, only one study, conducted in Japan, has considered this variable and reported a higher prevalence of $\mathrm{HBoV}$ during the winter compared to other seasons (Nakanishi et al. 2009).

Recently, HBoV-2 has been significantly associated with acute gastroenteritis (Arthur et al. 2009); however, the role of HBoV-1 and HBoV-3 in the aetiology of viral gastroenteritis has not yet been completely established. The inability to elucidate this role could be attributed, in part, to the frequent association of $\mathrm{HBoVs}$ with other gastroenteric viruses (Albuquerque et al. 2007, Arthur et al. 2009, Nakanishi et al. 2009, Chow et al. 2010). Studies conducted in Japan, Australia and South Korea have observed an association of $\mathrm{HBoV}$ with RVAs, adenoviruses, astroviruses and caliciviruses with a higher frequency 
of HBoVs in association with RVA and noroviruses (Arthur et al. 2009, Han et al. 2009, Nakanishi et al. 2009). In the present investigation, a co-infection rate of 31.8\% for HBoV-1 associated with RVA and Aichi virus was observed. Therefore, HBoV-1 was detected alone in a significant percentage of gastroenteritis cases, thereby suggesting a potential role of this agent in the context of acute gastroenteritis in the Central-West Region of Brazil.

The results of the genomic sequencing and phylogenetic analysis of a partial sequence of the NS1 gene showed that 11 of the analysed samples were characterised as $\mathrm{HBoV}-1$, whereas one sample was HBoV-3. The $\mathrm{HBoV}-1$ nucleotide sequences obtained in this study had a high level of identity with sequences previously identified in China, Sweden and Brazil (Allander et al. 2005, Albuquerque et al. 2007, Lau et al. 2007) and one of these isolates had a nucleotide sequence that was identical to others obtained in other regions in Brazil (Albuquerque et al. 2007). Furthermore, three samples had $100 \%$ nucleotide identity; two of these samples were from Brasília and one was from Campo Grande, which demonstrated the circulation of the same viral isolate in more than one state in the region. The only isolate characterised as HBoV-3 grouped with others that were previously identified in Australia and Brazil, which suggests viral dissemination in different parts of the world.

The results of this study reinforce the need for further investigations regarding HBoVs. These studies should be conducted in a larger number of individuals and in different populations while considering a broader age group and symptomatology. Furthermore, future studies should target different parts of the viral genome to achieve a better understanding of $\mathrm{HBoV}$ epidemiology as well as its related morbidities.

\section{ACKNOWLEDGEMENTS}

To Dr Norma Santos, from the Institute of Microbiology, Federal University of Rio de Janeiro, Brazil, for providing the $\mathrm{HBoV}$-positive controls.

\section{REFERENCES}

Albuquerque MCM, Rocha LN, Benati FJ, Soares CC, Maranhão AG, Ramirez ML, Erdman M, Santos N 2007. Human bocavirus infection in children with gastroenteritis, Brazil. Emerg Infect Dis 13: $1756-1758$.

Allander T, Tammi MT, Eriksson M, Byerkner A, Tiveljung-Lindell A, Anderson B 2005. Clonning of a human parvovirus by molecular screening of respiratory tract samples. Proc Natl Acad Sci USA 102: 12891-12896.

Andreasi MSA, Cardoso DDP, Fernandes SM, Tozetti IA, Borges AMT, Fiaccadori FS, Santos RAT, Souza M 2008. Adenovirus, calicivirus and astrovirus detection in fecal samples of hospitalized children with acute gastroenteritis from Campo Grande, MS, Brazil. Mem Inst Oswaldo Cruz 103: 742-744.

Arthur JL, Higgins GD, Davidson GP, Givney RC, Ratcliff RM 2009. A novel bocavirus associated with acute gastroenteritis in Australian children. PLos Pathog 5: e1000391.

Borges AMT, Teixeira JMS, Costa PSS, Giugliano LG, Fiaccadori FS, Franco RC, Diederichsen WMEB, Leite JPG, Cardoso DDP 2006. Detection of calicivirus from fecal samples from children with acute gastroenteritis in the West Central Region of Brazil. Mem Inst Oswaldo Cruz 101: 721-724.
Camarota SCT, Azevedo MSP, Martins RMB, Barbosa AJ, Júnior PAF, Araújo SV, Cardoso DDP 1992. Ocorrência de rotavírus e adenovírus em crianças de até 11 anos de idade sem sintomatologia de diarréia em Goiânia-GO. Rev Soc Bras Med Trop 25: 31-35.

Campe H, Hartberger C, Sing A 2008. Role of human bocavirus infections in outbreaks of gastroenteritis. J Clin Virol 43: 340-342.

Cardoso DDP, Brito WMED, Martins RMB, Kitajima EW, Souza MPM, Barbosa AJ 1989. Ocorrência de rotavirus e adenovirus em amostras fecais de crianças com gastrenterite na cidade de Goiânia. Rev Soc Bras Med Trop 22: 67-71.

Cardoso DDP, Soares CMA, Souza MBLD, Azevedo MSP, Martins RMB, Queiroz DAO, de Brito WMED, Munford V, Rácz ML 2003. Epidemiological features of rotavirus infection in Goiânia, Goiás, Brazil, from 1986 to 2000. Mem Inst Oswaldo Cruz 98: 25-29.

Cheng WX, Jin Y, Duan ZJ, Qi HM, Zhang Q, Yu JM, Duan ZJ 2008. Human bocavirus in children hospitalized for acute gastroenteritis: a case-control study. Clin Infect Dis 47: 161-167.

Chow BDW, Ou Z, Esper FP 2010. Newly recognized bocaviruses (HBoV, HBoV2) in children and adults with gastrointestinal illness in the United States. J Clin Virol 47: 143-147.

Costa PSS, Grisi SJFE, Cardoso DDP, Fiaccadori FS, Souza MBLD, Santos RAT 2004. Manifestações clínicas e epidemiológicas das infecções por rotavirus A. Pediatria (São Paulo) 3: 151-158.

Han TH, Kim CH, Park SH, Kim EJ, Chung JY, Hwang ES 2009. Detection of human bocavirus-2 in children with acute gastroenteritis in South Korea. Arch Virol 154: 1923-1927.

Huang Y, Mao P, Wang H 2009. Detection of and frequent co-infection with human bocavirus in faecal specimens from children in Wuhan, China. J Clin Microbiol Infect 16: 490-492.

ICTV - International Committee of Taxonomy of viruses 2008. [homepage on the Internet]. Parvoviridae 2008. Available from: ncbi.nlm.nib.gov/ictvdb/ictv/index.htm.

Jartti T, Hedman K, Jartti L, Ruuskanen O, Allander T, SoderlundVenemo 2012. Human bocavirus-the first 5 years. Rev Med Virol 22: 46-64.

Jin Y, Cheng W-X, Xu Z-Q, Liu N, Yu J-M, Li H-Y, Jin M, Li D-D, Zhang Q, Duan Z-J 2011. High prevalence of human bocavirus 2 and its role in childhood acute gastroenteritis in China. J Clin Virol 52: 251-253.

Kantola K, Sadeghi M, Antikainem J, Kirveskari J, Delwart E, Hedman K, Soderlund-Venermo 2010. Real-time quantitative PCR detection of four human bocaviruses. J Clin Microbiol 48: 4044-4050.

Kapoor A, Simmonds P, Slikas E, Li L, Bodhidatta L, Sethabutr O, Triki H, Bahri O, Oderinde BS, Baba MM, Bukbuk DN, Besser J, Bartkus J, Delwart E 2010. Human bocaviruses are highly diverse, dispersed, recombination prone and prevalent in enteric infections. J Infect Dis 201: 1633-1643.

Karalar L, Lindner J, Schimanski S, Kertai M, Segerer H, Modrow S 2009. Prevalence and clinical aspects of human bocavirus infection in children. Clin Microbiol Infect 16: 633-639.

Lau SKP, Yip CCY, Que TI, Lee RA, Au-Yeung RKH, Zhou B, So LY, Lau YL, Chan KH, Woo PCY, Yuen KY 2007. Clinical and molecular epidemiology of human bocavirus in respiratory and fecal samples from children in Hong Kong. J Infect Dis 196: 986-993.

Lee JI, Chung JY, Han TH, Song MO, Hwang ES 2007. Detection of human bocavirus in children hospitalized because of acute gastroenteritis. J Infect Dis 196: 994-997.

Monteny M, Niesters HGM, Moll HA, Berger MY 2007. Human bocavirus in febrile children - the Netherlands. Emerg Infect Dis 13: $180-182$. 
Nakanishi K, Tsugawa T, Honma S, Nakata S, Tatsumi M, Yoto Y, Tsutsumi H 2009. Detection of enteric viruses in rectal swabs from children with acute gastroenteritis attending the pediatric outpatient clinics in Sapporo, Japan. J Clin Virol 46: 94-97.

Oh DY, Silva PA, Hauroeder B, Diedrich S, Cardoso DPP, Schreier E 2006. Molecular characterization of the first Aichi viruses isolated in Europe and in South America. Arch Virol 151: 1199-1206.

Proença-Modena JL, Gagliardi TB, de Paula FE, Iwamoto MA, Criado MF, Camara AA, Acrani GO, Cintra OAL, Cervi MC, Arruda LKP, Arruda E 2011. Detection of human bocavirus mRNA in respiratory secretions correlates with high viral load and concurrent diarrhea. PLoS ONE 6: e21083.

Saitou N, Nei M 1987. The neighbor-joining method: a new method for reconstructing phylogenetic trees. Mol Biol Evol 4: 406-425.

Sanger F, Nicklen S, Chase AR 1977. DNA Sequencing with chain terminating inhibitors. Proc Natl Acad Sci USA 74: 5463-5468.

Santos N, Peret TCT, Humphrey CD, Albuquerque MCM, Silva RC, Benati FJ, Lu X, Erdman DD 2010. Human bocavirus species 2 and 3 in Brazil. J Clin Virol 48: 127-130.

Santos RAT, Borges AMT, Costa PSS, Teixeira JMS, Giugliano LG, Leite JPG, Cardoso DDP 2007. Astrovirus infection in children living in the Central West Region of Brazil. Mem Inst Oswaldo Cruz 102: 209-213.

Schildgen O, Müller A, Allander T, Mackay IM, Völz S, Kupfer B, Simon A 2008. Human bocavirus: passenger or pathogen in acute respiratory tract infections? Clin Micr Biol Rev 21: 291-304.
Silva PA, Santos RAT, Costa PSS, Teixeira JMS, Giugliano LG, Andreasi MSA, Leite JPG, Schreier E, Cardoso DDP 2009. The circulation of human astrovirus genotypes in the Central West Region of Brazil. Mem Inst Oswaldo Cruz 104: 655-658.

Sloots TP, McErlean P, Speicher DJ, Arden KE, Nissen MD, Mackay IM 2006. Evidence of human coronavirus HKU1 and human bocavirus in Australian children. J Clin Virol 35: 99-102.

Tompson JD, Gibson TJ, Plewniak F, Jeanmougin F, Higgins DG 1997. The CLUSTALX Windows interface: flexible strategies for multiple sequence alignment aided by quality analysis tools. Nucleic Acids Res 25: 4876-4882.

Tozer SJ, Lambert SB, Whiley DM, Bialasiewicz S, Lyon MJ, Nissen MD, Sloots TP 2009. Detection of human bocavirus in respiratory, fecal and blood samples by real-time PCR. $J$ Med Virol 81: 488-493.

Vicente D, Cilla G, Montes M, Pérez-Yarza EG, Pérez-Trallero E 2007. Human bocavirus, a respiratory and enteric virus. Emerg Infect Dis 13: 636-637.

Xu Z, Cheng W, Li B, Lan B, Duan Z 2011. Development of a realtime PCR assay for detecting and quantifying human bocavirus 2. J Clin Microbiol 49: 1537-1541.

Yu JM, Li DD, Xu ZQ, Cheng WX, Zhang Q, Li HY, Cui SX, Jin M, Yang SH, Fang ZY, Duan ZJ 2008. Human bocavirus infection in children hospitalized with acute gastroenteritis in China. J Clin Virol 42: 280-285. 